\title{
PTEN hamartoma tumor syndrome
}

INSERM

\section{Source}

INSERM. (1999). Orphanet: an online rare disease and orphan drug data base. PTEN hamartoma tumor syndrome. ORPHA:306498

PTEN hamartoma tumor syndrome (PHTS) is a term defining a group of clinically heterogeneous disorders united by a germline PTEN mutation and the involvement of derivatives of all 3 germ cell layers, manifesting with hamartomas, overg rowth and neoplasia. Currently, subsets carrying clinical diagnoses of Cowden syndrome, BannayanRiley-Ruvalcaba syndrome, Proteus and Proteus-like syndromes and SOLAMEN syndrome (see these terms) belong to PHTS. 